\title{
PSIKOLOGI “HIJAU” (GREEN PSYCHOLOGY) SEBAGAI ALTERNATIF UNTUK PENINGKATAN KESEJAHTERAAN PSIKOLOGIS MASYARAKAT PERKOTAAN
}

\author{
Murty Magda Pane \\ Character Building Development Center, BINUS University \\ Jln. Kemanggisan Ilir III No. 45, Kemanggisan-Palmerah, Jakarta Barat 11480 \\ murty.pane@binus.ac.id
}

\begin{abstract}
This article describes so many disasters caused by the decrease of environment quality, or even pollution and environmental destruction, are due to society's bad behaviors. The decrease of environment quality, as consequences, may cause lower people's lives quality phisically and mentally as well. To overcome the problem, it is proposed a psychology intervension, called "green" psychology.
\end{abstract}

Keywords: environment quality, urban peoples's lives, life quality, green psychology

\begin{abstract}
ABSTRAK
Artikel ini menggambarkan bahwa banyaknya bencana yang disebabkan oleh turunnya kualitas lingkungan, atau bahkan tercemar dan rusaknya lingkungan perkotaan, mayoritas disebabkan oleh perilaku masyarakatnya yang tidak baik. Penurunan kualitas lingkungan ini pada akhirnya juga dapat menurunkan kualitas hidup masyarakat secara fisik maupun mental. Untuk mengatasinya, disodorkan sebuah alternatif sebagai intervensi, yaitu intervensi secara psikologis yang disebut sebagai psikologi "hijau".
\end{abstract}

Kata kunci: kualitas lingkungan, kehidupan masyarakat perkotaan, kualitas hidup, psikologi "hijau" 


\title{
PENDAHULUAN
}

Tahun terakhir ini kita lihat banyaknya "bencana” yang menimpa kota Jakarta, baik bencana alam, seperti banjir dan kebakaran, maupun "bencana" sosial, seperti kerusuhan, tawuran antar-pelajar ataupun warga. Belum lagi banyaknya jenis penyakit baru, atau penyakit yang sudah ada sejak lama tetapi bergeser tingkat keparahannya menjadi lebih tinggi. Bencana yang beragam ini tentunya dapat menurunkan kualitas hidup masyarakat perkotaan. Hal ini dapat dilihat pada pernyataan dari Kementerian Lingkungan Hidup berikut ini:

\begin{abstract}
"Berdasarkan data dari BNPB Tahun 2011, tren bencana di Indonesia terus meningkat dari tahun ke tahun. Bencana yang terjadi tersebut umumnya berkaitan dengan hidrometeorologi (kekeringan, tanah longsor, puting beliung dan gelombang pasang) yang terjadi rata-rata hampir 80 \% dari total bencana di Indonesia. Bahkan menurut catatan International Disaster Database (2007), 10 kejadian bencana terbesar di Indonesia yang terjadi dalam periode waktu 1907 - 2007 terjadi setelah tahun 1990-an dan sebagian besar merupakan bencana yang terkait dengan iklim khususnya banjir, kemudian kekeringan, kebakaran hutan, dan ledakan penyakit."
\end{abstract}

Juga pernyataan berikut:

"Banjir dan kekeringan merupakan fenomena rutin yang dihadapi di beberapa daerah dengan kerugian yang tidak kecil seperti banjir Februari 2007 di wilayah Jabodetabek selama 5 hari mencapai kerugian 8,6 trilyun atau setara dengan 48 \% APBD DKI tahun 2006 dengan korban 60 orang dari 263.416 pengungsi." (MENLH, 2012)

Hal ini tentunya tidak mengherankan karena telah banyak terjadi pencemaran, terutama pada udara, yang berpotensi untuk menurunkan kualitas lingkungan kota Jakarta. Data pengukuran kualitas udara Indonesia pada umumnya, dan Jakarta secara khusus, untuk beberapa parameter dapat dilihat pada grafik dan tabel berikut.

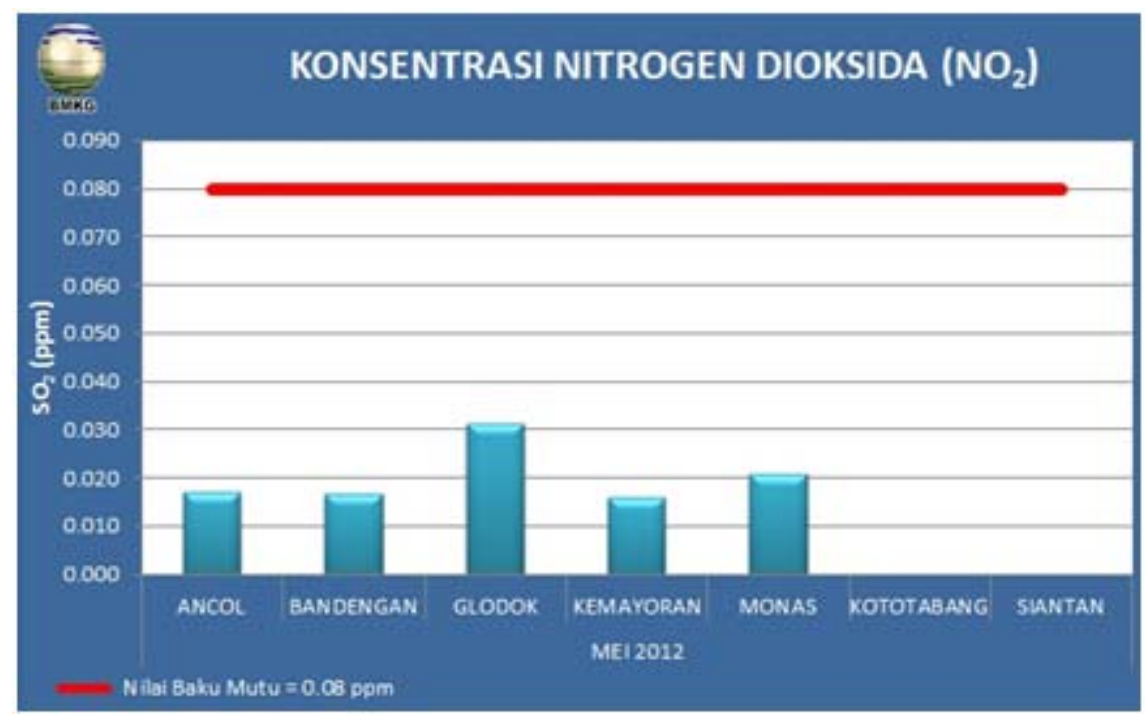

Gambar 1 Grafik Data Pengukuran Nitrogen Dioksida $\left(\mathrm{NO}_{2}\right)$ 
Tabel 1 Data Pengukuran Parameter Partikulat (Debu/Suspended Particulate Matter (SPM))

\begin{tabular}{|c|c|c|}
\hline SUMATERA & JAWA & KALIMANTAN \\
\hline BAWIL-1 MEDAN & ANCOL - JAKARTA & SUPADIO - PONTIANAK \\
\hline SAMPALI - MEDAN & BANDENGAN - JAKARTA & TJILIK RIVUT - PALANGKARAYA \\
\hline SP. TIGA - PEKANBARU & GLODOK - JAKARTA & BANJAR BARU - BANJARMASIN \\
\hline KOTOTABANG - PADANG & KEMAYORAN - JAKARTA & TEMINDUNG - SAMARINDA \\
\hline SICINCIN - PADANG & MONAS - JAKARTA & \\
\hline TABING - PADANG & CILEDUG - TANGERANG & \\
\hline ST.THAHA - JAMBI & TANGERANG - TANGERANG & \\
\hline KENTEN - PALEMBANG & DARMAGA - BOGOR & \\
\hline BRANTI - LAMPUNG & CITEKO - CISARUA & \\
\hline P. BAAl - BENGKULU & BANDUNG & \\
\hline \multirow[t]{5}{*}{ MASGAR - LAMPUNG } & CILACAP & \\
\hline & SEMARANG & \\
\hline & YOGYAKARTA & \\
\hline & JUANDA - SURABAYA & \\
\hline & KR.PLOSO - MALANG & \\
\hline SULAWESI & BALI, NTB, NTT & IRIAN JAYA \\
\hline BAWIL-4 MAKASSAR & NGURAHRAI - BALI & PATIMURA - AMBON \\
\hline SAMRATULANGI - MANADO & ELTARI - KUPANG & MOKMER - BIAK \\
\hline WINANGUN - MANADO & SEAPARANG - MATARAM & ANGKASA PURA - JAYAPURA \\
\hline KAYUWATU - MANADO & NEGARA - BALI & \\
\hline \multicolumn{3}{|l|}{ PANAKUKANG - UJUNG PANDANG } \\
\hline \multicolumn{3}{|l|}{ BETO AMBARI - BAU-BAU } \\
\hline MUTIARA - PALU & & \\
\hline
\end{tabular}

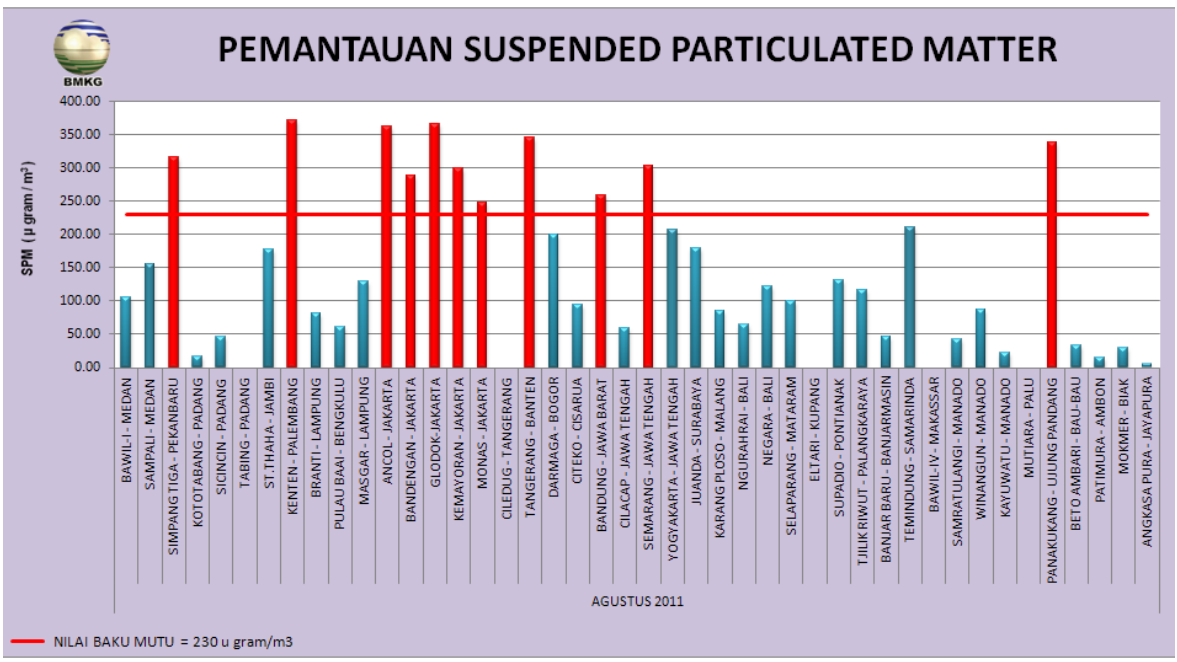

Gambar 2 Grafik Pengukuran Parameter Partikulat (Debu / Suspended Particulate Matter (SPM)) (Sumber: Badan Meteorologi Klimatologi dan Geofisika)

Catatan: Pengambilan data dilakukan oleh BMKG pada waktu yang berbeda

Sebagai informasi, $S P M$ dan $\mathrm{NO}_{2}$ termasuk dua dari beraneka ragam kontaminan pada udara yang dapat menurunkan fungsi organ paru-paru pada manusia.

Data di atas menunjukkan bahwa kualitas lingkungan kota Jakarta sudah cukup untuk dikategorikan termasuk dalam tingkatan rendah bagi fungsinya dalam mendukung kualitas hidup masyarakatnya. Hal ini seyogyanya membuat kita berpikir akan peran lingkungan hidup sekitar kita bagi tingkat kualitas hidup kita sendiri. Soegijoko bahkan mengatakan:

"Pelestarian lingkungan menjadi sangat penting tidak hanya dipandang dari segi fisik lingkungan - sebagai sumber daya alam yang dibutuhkan manusia untuk kehidupannya seperti air, udara, tanah, namun juga bagi kualitas hidup manusia. Lingkungan berpengaruh pada fungsi mental, hubungan sosial dan kesehatan fisik manusia. Dampak kerusakan lingkungan dapat berupa fisik dengan timbulnya berbagai penyakit seperti asma, diare, penyakit kulit, dan sebagainya. Selain itu dapat juga berupa dampak psikologis seperti stres akibat kebisingan, polusi dan suhu udara, serta keterbatasan gerak.” (Soegijoko, 2011) 
Bahkan telah ada studi tentang kebutuhan akan green space (n-Green) yang menyatakan bahwa terdapat hubungan yang kuat antara dimensi persepsi manusia dan kontribusi positif terhadap tingkat kebutuhan akan green space (n-Green score) - dimana pengembangan mental berkontribusi lebih besar daripada kesehatan fisik dan interaksi sosial (Halim, 2011).

Yang cukup mengejutkan adalah adanya data yang menunjukkan peningkatan jumlah orang yang menderita penyakit jiwa di perkotaan. Data per Juli 2008 saja menunjukkan jumlah pasien rawat inap di RSJ mengalami peningkatan terutama pada bulan Mei 2008 yakni mencapai 200 pasien. Ini adalah angka tertinggi selama satu semester 2008 untuk pasien rawat inap. Januari 2008 sebanyak 182 pasien, Februari 2008158 pasien, Maret 2008179 pasien, April 2008188 pasien, Mei 2008200 pasien dan Juni 2008165 pasien. Sedangkan untuk pasien rawat jalan di bulan Januari 2008 sebanyak 2.151 kunjungan, Februari 20081.923 kunjungan, Maret 20081.958 kunjungan, April 20081.152 kunjungan, Mei 20082.121 kunjungan, Juni 20082.141 kunjungan (data dari sebuah RSJ di Jawa Timur). Menurut dr. Fidiansyah, Sp.KJ, penyebab gangguan kejiwaan itu multifaktor, bukan hanya karena tekanan ekonomi, ujarnya menambahkan. Jika penderita gangguan jiwa ringan dan berat tidak segera ditangani, maka gejalanya akan bertambah berat dan bisa mengakibatkan munculnya perilaku anarkis dalam menghadapi persoalan pribadi dan sosial. Hal ini bisa dilihat dalam sejumlah kerusuhan yang dilakukan sekelompok masyarakat (Kompas, 9 Juli 2008). "Di daerah yang mengalami pembangunan pesat, selain penyakit menular seksual, saya perkirakan yang juga naik adalah masalah kesehatan jiwa. Ini terjadi di daerah-daerah yang 'dikarbit' untuk maju,” kata (mantan) Menteri Kesehatan almh. Endang Rahayu Sedyaningsih ketika membuka Konferensi Nasional Kebijakan Kesehatan Jiwa I dan Konferensi Nasional Psikiatri Komunitas II di Hotel Santika, Jakarta, dalam rangka peringatan Hari Kesehatan Jiwa Sedunia 10 Oktober 2011 yang lalu (sesawi.net). Penulis memang belum mendapatkan data yang paling baru, tetapi melihat trennya, apalagi dapat kita lihat semakin meningkatnya jumlah perilaku anarkis, bahkan tindak kejahatan hingga sekarang, diduga kuat jumlah dan intesitas penyakit jiwa yang diderita masyarakat perkotaan meningkat pesat.

Untuk intervensi alternatif masalah kesejahteraan psikologis masyarakat perkotaan tersebut, penulis ingin menawarkan konsep Green Psychology yang dilandasi oleh teori-teori dalam ilmu Psikologi Lingkungan agar kita dapat hidup lebih serasi dengan alam, yang pada akhirnya dapat hidup lebih serasi dengan masyarakat. Rumusan permasalahan dalam penelitian ini adalah bagaimana peran psikologi hijau dalam meningkatkan tingkat kesejahteraan psikologis masyarakat perkotaan. Tujuan penelitian ini adalah peran psikologi hijau dalam meningkatkan tingkat kesejahteraan psikologis masyarakat perkotaan.

Sebelum dilakukan pembahasan lebih dalam, sebaiknya penulis mendeskripsikan tentang psikologi lingkungan terlebih dahulu. Pengertian psikologi lingkungan dapat dijabarkan dalam beragam versi, misalnya: (1) Stokols \& Altman (1987): The study of human behaviour and well-being in relation to the sociophysical environment. (2) Russell \& Snodgrass (1987): The branch of Psychology concerned with providing a systematic account of the relationship between a person and the environment. (3) Bell, Fisher, Baum \& Greene (1996): The study of the molar relationships between behaviour experience and the built and natural environments.

Atau dapat diartikan sebagai berikut: (1) Suatu studi tentang perilaku manusia dan kesejahteraannya dalam hubungannya dengan lingkungan social dan fisik (Stokols \& Altman, 1987). (2) Suatu cabang dari ilmu psikologi yang memberi perhatian khusus dengan pemikiran sistematis atas hubungan antara seseorang dan lingkungannya (Russell \& Snodgrass, 1987). (3) Suatu studi tentang hubungan molaritas antara pengalaman perilaku dengan lingkungan alami dan buatan (Bell, Fisher, Baum \& Greene, 1996) (Sumber: American Psychology Association (APA) - Division 34).

Secara umum, psikologi lingkungan dapat didefinisikan sebagai suatu area keilmuan antardisiplin yang berfokus pada hubungan yang saling memengaruhi antara manusia dan sekitarnya (Wikipedia). Literatur terdahulu menekankan empat poin kunci yang membantu untuk membingkai 
psikologi lingkungan dalam spektrum studi perkotaan dan praktik perencanaannya: penekanan program terhadap karakteristik spasio-fisik dari lingkungan mana perilaku terjadi; kekhususan dari metode yang diadopsi; orientasi terhadap masalah yang jelas relevansi sosialnya; orientasi penelitian interdisipliner (Bonnes dan Secchiaroli, 59 dalam Lew, 2006).

Green Psychology sebagai suatu pengembangan ilmu Psikologi tidak luput untuk membahas interaksi manusia dengan lingkungan fisik, terutama terkait dengan kondisi bumi yang telah mengalami krisis. Disiplin keilmuan Psikologi Lingkungan ataupun Green Psychology memang semakin banyak diperhatikan dan mulai dilakukan pengembangan-pengembangan mengingat bahwa sebagian besar kerusakan lingkungan disebabkan oleh tingkah laku manusia.

Contoh kasus yang jelas terlihat adalah kebutuhan akan perumahan tentunya semakin dirasakan seiring dengan pertambahan penduduk yang demikian cepat di Indonesia, khususnya di kota-kota besar (dalam hal ini Jakarta). Selain pertambahan penduduk alami, di kota-kota besar yang pembangunannya pesat tentunya banyak diserbu oleh pendatang yang ingin mencari kerja, sehingga tak mengherankan laju pertumbuhan penduduknya demikian tinggi karena ada tambahan pertambahan penduduk dari arus migrasi.

Jumlah penduduk yang terus meningkat ini tentunya menyebabkan bertambahnya terpakainya lahan-lahan yang sebelumnya banyak yang kosong atau tanah milik Pemerintah atau bahkan lahan kososng yang tidak terjaga. Hal ini menyebabkan kebutuhan tanah semakin meningkat setiap tahunnya sehingga menyebabkan lahan terbuka hijau menjadi berkurang.

Bukan hanya penggunaan lahan yang semakin meningkat dalam masalah pembangunan dan perkembangan kota berikut masyarakatnya. Peningkatan taraf hidup masyarakat bahkan juga telah menyebabkan terus meningkatnya penggunaan kendaraan bermotor dalam kehidupan keseharian mereka. Padahal seperti telah diketahui, pengoperasian kendaraan bermotor banyak menggunakan bahan bakar minyak yang selain menyebabkan pemborosan energi, juga banyak mengeluarkan gas buang karbon monoksida (CO). Pembuangan gas CO di jalan raya pada jam sibuk berkisar antara 25 $125 \mathrm{mg} / \mathrm{m}^{3}$, bahkan pada daerah yang termasuk tinggi pencemaran udaranya kadar gas CO yang dibuang mencapai $50 \mathrm{mg} / \mathrm{m}^{3}$ rata-ratanya. Kualitas udara yang rendah ini banyak memapar orangorang yang sering berada di jalan raya seperti polisi, tukang parkir, pedagang kaki lima, atau bahkan orang-orang yang berada di dalam kendaraan yang tidak menggunakan mesin pendingin dengan berbagai alasan (Iskandar, 2011).

Banyaknya penggunaan kendaraan bermotor ini bukan hanya menyebabkan pencemaran udara, tetapi juga tingginya tingkat kemacetan lalu lintas. Sedangkan kemacetan itu sendiri juga banyak memberikan dampak negatif yang di antaranya adalah: kerugian waktu, karena kecepatan perjalanan yang rendah; pemborosan energi, karena pada kecepatan rendah konsumsi bahan bakar lebih rendah; keausan kendaraan lebih tinggi, karena waktu yang lebih lama untuk jarak yang pendek, radiator tidak berfungsi dengan baik dan penggunaan rem yang lebih tinggi; meningkatkan polusi udara karena pada kecepatan rendah konsumsi energi lebih tinggi, dan mesin tidak beroperasi pada kondisi yang optimal; meningkatkan stres pengguna jalan; dan mengganggu kelancaran kendaraan darurat seperti ambulans, pemadam kebakaran dalam menjalankan tugasnya (Wikipedia Indonesia, 2012).

Produksi sampah di Jakarta yang mencapai lebih dari 6.500 ton per hari, membuat masalah sampah yang ada di Jakarta menjadi sebuah permasalahan yang serius yang harus segera ditangani. Selama ini Bantar Gebang yang ada di daerah Bekasi hanya menjadi satu-satunya tempat pembuangan akhir sampah-sampah yang ada di sekitar Jakarta. Akan tetapi, tidak mungkin selamanya Bantar Gebang menjadi tempat akhir pembuangan sampah karena lama kelamaan pasti volume sampah yang ada di Bantar Gebang akan meningkat sedangkan tempatnya pun terbatas. Kemampuan menghadapi dan menyesuaikan diri terhadap situasi baru secara cepat dan efektif: kemampuan menggunakan 
konsep abstrak secara efektif, kemampuan menggunakan pertalian-pertalian dan belajar dengan cepat sekali (Prabowo, 2012 dalam Pantona News).

Bagaimanakah suatu kota dapat dikatakan layak untuk dihuni oleh manusianya? Jawaban bagi pertanyaan ini dapat dijawab dengan memerhatikan bagan berikut:

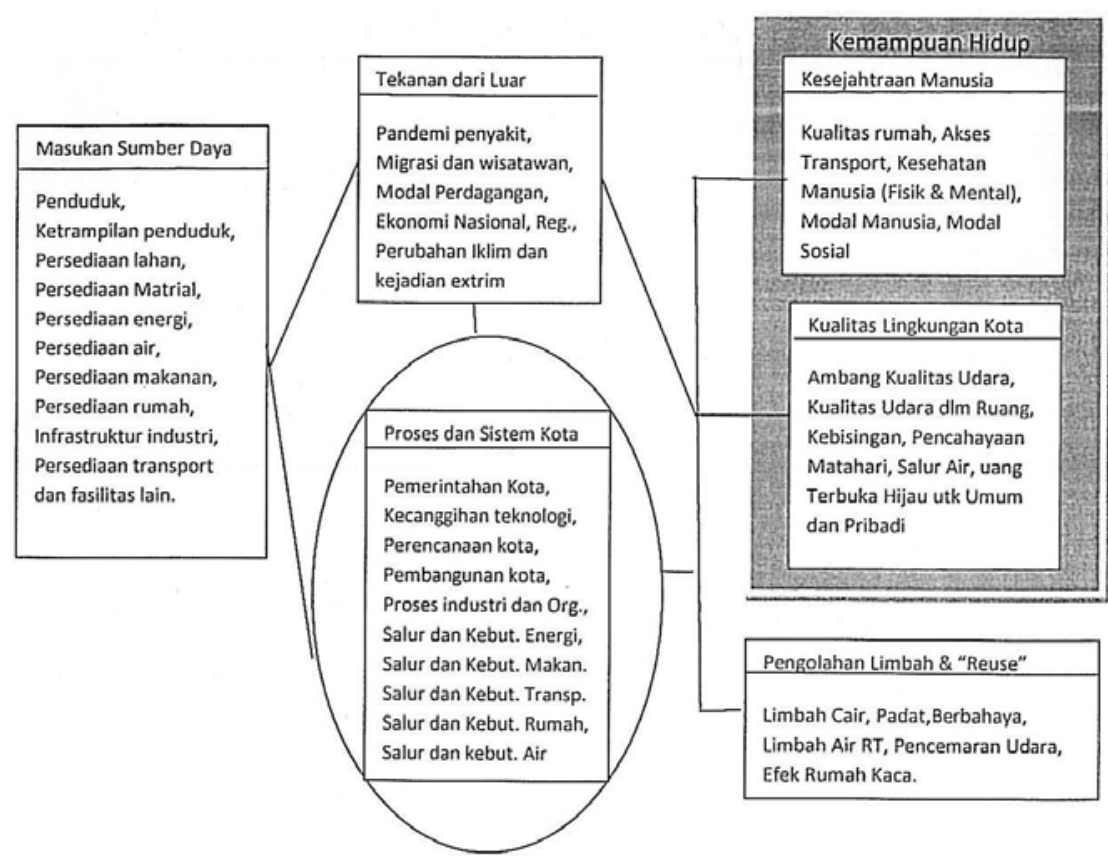

Gambar 3 Bagan Kerangka Kerja untuk Keberlanjutan Pembangunan Kota (Sumber: Newton (2006); Seetharam K. \& Belinda Y. (hal. 192) dalam Iskandar (2011))

Berdasarkan bagan kerangka kerja di atas, terlihat bahwa kota Jakarta (mungkin juga hal yang sama terjadi pada kota-kota besar lain di Indonesia) belum memenuhi kelayakan hidup bagi manusia. Jelas bahwa masalah perkotaan perlu ditata ulang. Hal ini dimaksudkan agar terjadi kelayakan hidup dan kebahagiaan manusia secara psikologis dan sosial.

Melihat berbagai permasalahan yang terdapat pada lingkungan, maka terlihat bahwa sangat erat kaitannya antara Green Psychology dengan kesehatan manusia (fisik dan mental). Namun demikian, telah diketahui pula bahwa permasalahan utama yang dihadapi dalam interaksi antara manusia dan lingkungannya terdapat pada manusianya sendiri. Banyak perilaku manusia yang merusak lingkungan. Oleh karena itu, perlu ada langkah-langkah intervensi yang dapat dilakukan terhadap manusianya. Dengan demikian diharapkan terjadi hubungan serasi antara manusia dan lingkungannya.

Hal menarik lain dalam hubungan manusia dengan lingkungan sekitarnya adalah identitas tempat dan kesadaran lingkungan. Identitas tempat adalah substruktur dari identitas diri seseorang yang berisikan pengetahuan mengenai lingkungan fisik tempat dia hidup. Hal ini terkait dengan tempat yang berarti dan secara emosi memiliki makna hidup bagi dirinya. Namun demikian, muncullah pertanyaan: mengapa mereka berperilaku yang merusak lingkungan? Bagaimana mereka memaknai lingkungan sekitarnya? Apakah mereka memaknai lingkungan sebagai objek yang harus dimanfaatkan, dan bukan sebagai sesuatu yang harus dilindungi? 
Apabila mereka memaknai lingkungannya sebagai obyek yang harus dimanfaatkan untuk dirinya, identitas tempat hanya diketahui sebagai tempat mereka pernah berinteraksi dengan lingkungannya. Manusia dalam berinteraksi dengan lingkungannya tidak memikirkan orang lain yang juga memanfaatkan lingkungan tersebut. Mereka hanya mengenali lingkungannya tersebut sebagai tempat mereka tinggal atau pernah tinggal di dalamnya. Makna tempat tinggal bagi mereka hanya sebagai tempat mereka pernah tinggal. Mereka tidak merasa bahwa lingkungan sebagai tempat tinggalnya harus dipelihara agar menyenangkan. Makna pemeliharaan mengenai lingkungan nampaknya tidak dimiliki oleh mereka, tetapi makna pemanfaatan nampak lebih kental.

Namun demikian, apabila penduduk di suatu lokasi tersebut menghadapi permasalahan dengan pihak lain, mereka akan mempertahankan lahan mereka, misalnya pada kasus penggusuran. Dalam kasus penggusuran tersebut, mereka mengidentifikasikan diri sebagai pihak yang memiliki lahan tersebut dan melindunginya. Mereka dapat mengekspresikan diri bahwa lahan tersebut adalah lahan yang harus dipertahankan. Akan tetapi di pihak lain, ketika tidak ada masalah yang mengancam, mereka tidak berusaha menjaga lingkungannya dengan baik. Hal ini dapat terlihat misalnya dari perilaku membuang sampah tidak pada tempatnya, atau tidak sesuai dengan peruntukannya, misalnya sampah organik dibuang ke tempat sampah nonorganik, dan sebaliknya.

Melihat uraian-uraian dari paragraf di atas, dapat dikatakan bahwa kerusakan lingkungan lebih banyak dilakukan manusia ketika berinteraksi dengan lingkungan alam. Walaupun mereka tinggal di suatu lokasi, cukup banyak terlihat perilaku orang yang tidak dapat berinteraksi dengan lingkungan dengan baik. Yang menjadi pertanyaan adalah: mengapa perbuatan tersebut terus diulang, sehingga menjadi perilaku yang relative menetap? Sadar atau tidakkah mereka bahwa perilaku mereka tersebut kurang arif dalam berinteraksi dengan lingkungan?

Penelitian pernah dilakukan oleh Iskandar mengenai perilaku membuang sampah di sungai. Pada dasarnya penduduk yang tinggal di sepanjang sungai mengetahui bahwa perilakunya adalah salah. Penduduk tahu bahwa apabila mereka membuang sampah di sungai dapat menyebabkan banjir dan mengotori sungai. Penduduk pun tahu bahwa sebaiknya mereka membuang sampah di tempat yang telah ditentukan. Penduduk juga telah mengetahui bahwa untuk membuang sampah harus dipilah terlebih dahulu antara sampah organik dan nonorganik. Dengan demikian, secara kognitif mereka sudah tahu yang harus dilakukan dalam hal membuang sampah.

Sikap penduduk terhadap membuang sampah yang benar adalah positif. Namun demikian, perilaku mereka tetap membuang sampah tidak pada tempatnya. Kondisi tersebut membuktikan bahwa sikap yang positif terhadap sesuatu belum tentu membuat tingkah lakunya pun positif atau linier. Hal ini menunjukkan ada variabel lain yang memengaruhi terjadinya suatu perilaku. Dengan kata lain, sikap bukanlah satu-satunya variabel yang memengaruhi kecenderungan untuk berperilaku tertentu.

Proses internalisasi nilai, aturan mengenai perilaku membuang sampah kelihatannya tidak berjalan dengan baik. Mereka hanya sekadar tahu bahwa ada aturan mengenai membuang sampah, tetapi tidak diinternalisasikan. Hal ini dimungkinkan jika faktor lingkungan sekitar mereka pun tidak mendukung proses internalisasi. Mereka saling mengamati tentang perilakunya dalam membuang sampah, misalnya tetangga yang membuang sampah tidak pada tempatnya. Dengan demikian, terjadi proses belajar yang menghasilkan tentang cara membuang sampah tidak pada tempatnya pun tidak apa-apa. Selain itu pula, tempat sampah yang disediakan agak jauh. Mereka melihat tempat yang dekat rumahnya adalah sungai, sehingga tingkah laku membuang sampah di sungai pun terjadi.

Perilaku membuang sampah yang tidak sesuai dengan tempatnya diperkuat dengan adanya konsistensi pengawasan dari pihak pemerintah setempat. Tidak adanya sistem reward dan punishment akan semakin menguatkan perilaku yang mendukung membuang sampah tidak pada tempatnya. Sebagai hasilnya, maka pada diri individu penduduk terbentuk dalam pemetaan kognitif, bahwa tempat untuk membuang sampah adalah di sungai. 
Perilaku membuang sampah tidak pada tempatnya ini, menunjukkan bahwa orang tersebut hanya memikirkan dirinya sendiri. Mereka tidak berpikir untuk kepentingan lain yang lebih besar, atau setidaknya turut memikirkan orang lain. Apabila kasus membuang sampah dianalogikan dengan perilaku yang lain, nampak jelas bahwa perilaku tersebut berorientasi pada kepentingan dirinya. Perilaku menebang hutan sembarangan misalnya, para pelakunya tidak berpikir bahwa tindakan tersebut akan menyebabkan ekosistem sekitarnya terganggu. Demikian juga dengan pemilihan bahan bakar yang lebih murah padahal bahan bakar tersebut lebih tidak ramah lingkungan.

Sebagaimana telah diuraikan sebelumnya bahwa perilaku yang kurang arif terhadap lingkungan cukup banyak, ini berarti bahwa lingkungan sosialnya pun memiliki perilaku yang hampir sama. Dengan demikian, perilaku yang keliru dalam memanfaatkan lingkungan tidak akan mendapatkan kontrol sosial dari warganya sendiri. Dinamika perilaku masyarakat yang demikian menyebabkan hubungan yang tidak serasi antara manusia dengan lingkungannya. Hal ini sangat mungkin terjadi di Indonesia, khususnya Jakarta. Dengan kata lain, jika tidak ada sistem kontrol yang kuat, pihak lain sangat mungkin akan mementingkan diri sendiri, sehingga dalam interaksi manusia Indonesia dengan lingkungannya menjadi tidak serasi. Interaksinya mempunyai kecenderungan untuk mengalami konflik dengan lingkungannya.

Berdasarkan uraian pada bagian sebelumnya, terlihat bahwa interaksi antara manusia dengan lingkungan alaminya kurang berimbang. Manusia lebih banyak mengubah dan memanfaatkan lingkungan dengan tidak arif, sehingga banyak dampak negatif yang terjadi akibat interaksi yang kurang baik ini. Untuk mengembalikan pada hubungan yang berimbang, perlu adanya suatu intervensi secara psikologis.

Mengapa diperlukan intervensi psikologis? Karena permasalahan utama dalam hubungan manusia dengan lingkungan alami sekitarnya terdapat pada manusianya. Perilaku manusia dalam berinteraksi dengan lingkungan alaminya banyak merugikan lingkungan tersebut ketika interaksi terjadi, walaupun untuk memantapkan perubahan perilaku manusia tersebut diperlukan juga disiplin ilmu yang lain. Dengan demikian, dalam penerapan green psychology diperlukan suatu metode psikologi tertentu dalam melakukan asesmen dan intervensinya.

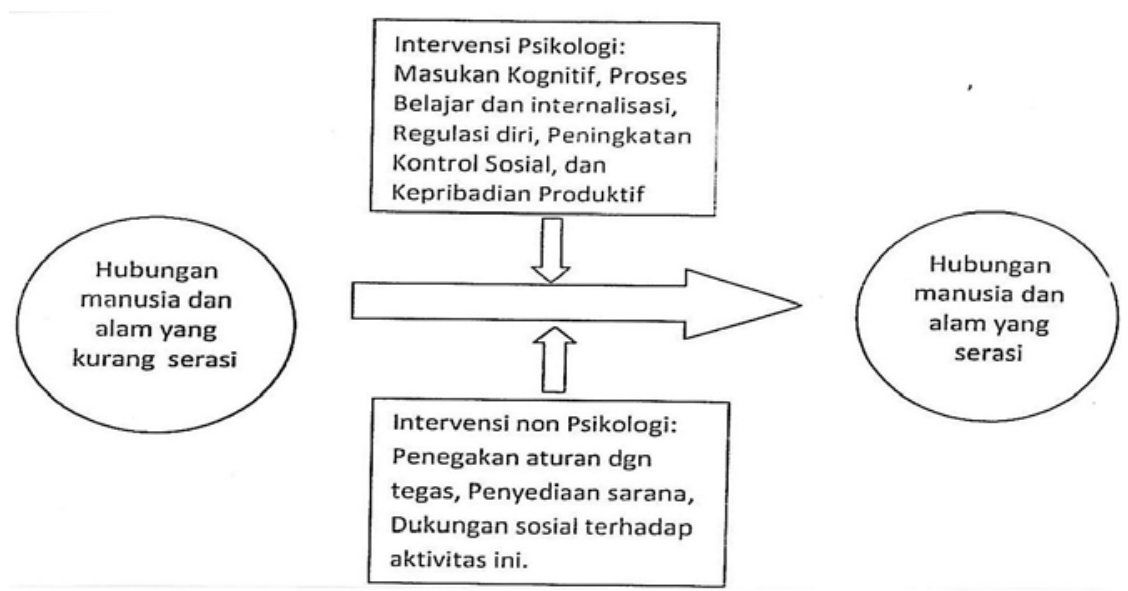

Gambar 4 Bagan Intervensi Psikologi dan Non-Psikologi

(Sumber: Iskandar, 2011)

Masukan kognitif merupakan pengetahuan mengenai hubungan yang serasi dengan lingkungan alam. Pengetahuan ini diperlukan untuk mencapai kebahagiaan hidup dalam berinteraksi dengan alam, apabila kondisi alamnya sehat. Namun bila kondisi alamnya tidak sehat, dapat muncul 
berbagai masalah yang lain, misalnya timbulnya wabah penyakit, yang tentunya dapat menyebabkan penurunan kualitas kesehatan fisik manusia. Masukan kognitif demikian perlu untuk menggugah masyarakat akan pentingnya hubungan yang serasi dengan alam.

Untuk mengubah perilaku manusia diperlukan proses belajar. Proses belajar ini tidak sekadar memasukkan ilmu pengetahuan ke kognisi, tetapi diperlukan juga penghayatan dan pengalaman yang dialami selama belajar. Berbagai teori tentang belajar dapat dipilih sesuai dengan kondisi masyarakat. Dengan demikian proses belajar dapat berlangsung secara efektif dan peraturan yang ada dapat tersosialisasikan dan diinternalisasi dengan baik.

Regulasi diri juga perlu dilatih kepada masyarakat yang masih memperlakukan lingkungan alami dengan kurang baik. Dengan adanya regulasi diri yang baik, maka masyarakat dapat mempertimbangkan perilaku yang seharusnya dilakukan dan tidak dilakukan terhadap lingkungan alami mereka. Individu yang dapat memberlakukan regulasi diri dengan baik akan mampu mengatur kognisi, emosi, dan motivasinya dalam berinteraksi dengan lingkungan alaminya hingga berjalan dengan baik. Dengan demikian, ketika ia akan melakukan interaksi dengan lingkungan alaminya, dinamika intrapsikis akan berjalan dengan baik sehingga menyebabkan ia akan berperilaku dengan baik pula.

Kemampuan dan keberanian individu untuk menegur anggota masyarakat yang melanggar perlu ditingkatkan. Artinya kepedulian anggota masyarakat terhadap perilaku yang kurang baik perlu ditingkatkan. Namun demikian, agar yang dtegur tidak merasa tersinggung dan yang ditegur mau menerima umpan balik dari pihak lain, maka perlu dilatih juga keterampilan berkomunikasi dengan efektif. Dengan demikian kontrol sosial dari anggota masyarakat dapat diharapkan berjalan dengan baik.

Mengapa perlu dikembangkan perilaku produktif? Seperti telah kita ketahui bahwa kondisi masyarakat Indonesia, terutama saat ini, lebih cenderung memiliki need for power yang cukup tinggi dengan dimensi personal power. Kondisi demikian tentunya kurang baik karena menyebabkan tiap individu dalam masyarakat lebih berfokus pada kebutuhan pribadinya, sehingga dalam berinteraksi dengan lingkungan alaminya pun terbawa dengan cara memanfaatkan lingkungan alam untuk kepentingannya. Oleh karena itu, dirasakan perlu dikembangkan kepribadian produktif.

Kepribadian produktif ini terdiri dari 3 aspek, yaitu: self esteem, identity, dan social responsibility. Individu yang memiliki self esteem yang baik akan selalu berorientasi pada prestasi, kreatif, sehingga keberadaan dirinya akan senantiasa bermanfaat. Sedangkan dengan identity yang baik menyebabkan integritas diri akan ditampilkan dalam berinteraksi dengan lingkungannya. Demikian pula dengan adanya social responsibility yang baik, maka ia akan menjadi pribadi yang matang, bertanggung jawab, dan mampu berkomunikasi dengan baik serta mampu mengikuti norma sosial yang ada. Oleh karena itu dalam menjaga lingkungan yang baik, diperlukan manusia dengan kepribadian produktif. Apabila seseorang lebih menonjol dalam need for power-nya dengan dimensi personal power, lingkungan alaminya lebih memiliki kemungkinan untuk rusak karena cenderung dimanfaatkan untuk dirinya, bukan untuk kepentingan bersama atau umum.

Untuk mewujudkan hal ini tentunya ahli dalam bidang psikologi tidak mungkin bekerja sendiri sebagai bidang ilmu yang mono disiplin. Mereka juga membutuhkan rekan kerja dari disiplin ilmu yang lain yang selain ilmuwan juga diperlukan praktisi professional yang dapat melaksanakan kegiatan-kegiatannya. Disiplin ilmu yang yang dibutuhkan dalam konteks green psychology di antaranya adalah: Teknik Lingkungan, Planologi, Sipil, Arsitektur Lansekap, Kehutanan, Pertanian, Arsitektur, Hukum, Sosiologi, Antropologi, dan sebagainya. Sedangkan institusi yang perlu terlibat adalah kepolisian, pemerintah daerah, kejaksaan, kehakiman, dan badan legislatif (Iskandar, 2011). 
Penggunaan pendekatan secara keilmuan psikologi ini tidak hanya dapat digunakan sebagai media intervensi saja. Sepertinya kita sudah pula harus melirik pendekatan green psychology ini sebagai salah satu metode alternatif perawatan psikologis bagi para penderita penyakit jiwa, atau minimal orang yang mengalami penurunan kesejahteraan psikologis yang cukup signifikan. Alternatif ini mulai banyak digunakan sebagai alternatif perawatan psikologis. Pengaturan suasana alam telah dibuktikan dalam sebuah literatur memiliki manfaat terapeutik terhadap fisik dan psikologis (Corbett \& Milton, 2011).

\section{METODE PENELITIAN}

Metode yang digunakan adalah studi kepustakaan (studi literatur). Data yang digunakan pada penelitian ini adalah data sekunder.

\section{HASIL DAN PEMBAHASAN}

Pertama-tama Penulis ingin membuat penekanan terhadap penggunaan terminologi. Terminologi green psychology sejauh yang dapat penulis lihat memang masih berupa konsep, walaupun sudah ada ilmu psikologi lingkungan (environmental psychology). Pemilihan penggunaan terminologi, menurut hemat penulis, tidak perlu dipermasalahkan. Hanya saja perlu diingat bahwa terminologi "hijau" (green) disini bermakna "RAMAH LINGKUNGAN". Jadi tidaklah tepat jika ada pihak yang mengartikan terminologi "hijau" (green) disini dengan membatasinya dalam hubungannya dengan keberadaan lingkungan yang hijau dalam arti yang sebenarnya, misalnya hutan yang masih lebat dan subur, atau taman-taman juga area-area tertentu yang penuh ditumbuhi dengan aneka ragam tumbuhan sehingga menghijau warnanya. Jadi, apabila kita ingin mempraktikkan perilaku "hijau", aktivitas yang harus dilakukan adalah menanam pohon. Hal ini bukannya salah, hanya saja telah terjadi pemaknaan terminologi yang kurang tepat. Seakan-akan perilaku yang ramah lingkungan (di sini disebut dengan "hijau") hanyalah menanam pohon. Padahal perilaku membuang sampah pada tempatnya pun sudah dikategorikan dengan perilaku "hijau".

Melihat bagan intervensi psikologi dan non-psikologi untuk meningkatkan kesadaran lingkungan individu, diperlukan banyak media sosialisasi sebagai bentuk masukan kognitif yang didukung dengan peraturan perundangan yang kuat berikut penyediaan sarana dan prasarana agar proses belajar dan internalisasi diri bisa dipercepat yang juga menyebabkan proses regulasi diri pun bisa lebih cepat lagi. Pada akhirnya, proses-proses ini dapat membentuk individu dengan pribadi yang lebih produktif dalam arti luas.

Untuk itu, perlu keterlibatan berbagai pihak dari berbagai kalangan yang berasal dari berbagai disiplin ilmu untuk dapat mewujudkannya. Seperti dapat dibaca pada definisi "Psikologi Lingkungan" secara umum yaitu "suatu area keilmuan antar-disiplin yang berfokus pada hubungan yang saling memengaruhi antara manusia dan sekitarnya”, maka tidaklah efektif jika kalangan yang bergelut di bidang psikologi yang khusus membidangi perilaku ramah lingkungan bekerja sendiri. Sudah saatnya masyarakat Jakarta pada khususnya, dan Indonesia pada umumnya, mencoba bekerja sama satu sama lain sebagai salah satu bentuk kepedulian terhadap lingkungan (dalam hal ini sosial). Harus diingat bahwa egoisme pada akhirnya menyebabkan lingkungan alami menjadi rusak, atau minimal menurun kualitas atau daya dukungnya. Penurunan kualitas lingkungan ini berakibat kembali lagi berbagai masalahnya kepada manusia, sehingga manusia pun menjadi korbannya. Jika hal ini dapat dihilangkan, atau minimal, dikurangi dengan bersama-sama, diharapkan kualitas hidup masyarakat 
Indonesia pada umumnya, dan Jakarta khususnya, sebagai kota terbesar di Indonesia, yang juga merupakan ibukota dan contoh bagi kota-kota lain di Indonesia, dapat lebih ditingkatkan.

\section{SIMPULAN}

Mengingat kondisi lingkungan fisik dan sosial kota-kota besar di Indonesia, terutama Jakarta, saat ini sudah semakin memprihatinkan, maka konsep green psychology diharapkan dapat turut memberikan kontribusi terhadap perbaikan kualitas lingkungan. Memerhatikan telah banyak pembuktian-pembuktian bahwa kualitas lingkungan yang baik berasal dari manusia dan juga sangat berguna bagi manusia, maka tidaklah berlebihan bila konsep green psychology dapat dilaksanakan secara bersinergi oleh berbagai pihak dengan beraneka ragam disiplin ilmu dengan melepaskan egonya masing-masing sehingga dapat bekerja sama dengan baik. Akhir kata, penulis menekankan bahwa green psychology ini adalah sebuah konsep yang ditawarkan. Seiring dengan terus berlangsungnya penelitian untuk perkembangan ilmu psikologi lingkungan, maka konsep green psychology ini tentunya masih memerlukan penelitian dan pengembangan lebih lanjut.

\section{DAFTAR PUSTAKA}

Halim, D. K., \& Weber, C. (2011). The Need of Green Space (n-Green) among French and Indonesian Urban Dwellers. Jakarta: Universitas Pancasila, Seminar Nasional - "Living Harmony with Green Psychology”.

Iskandar, Z. (2011). “Green Psychology” dan Kesehatan. Jakarta: Universitas Pancasila, Seminar Nasional - "Living Harmony with Green Psychology".

Lew, E. (2006). The Power of Place - The Application of Environmental Psychology in Urban Planning. San Fransisco: San Fransisco State University.

Soegijoko, B. T. S. (2011). Ruang Terbuka Hijau (RTH) dalam Perspektif Tata Kota. Jakarta: Universitas Pancasila, Seminar Nasional - "Living Harmony with Green Psychology”. 